Transcontinentales

continentales

Sociétés, idéologies, système mondial

2 | 2006

Afrique plurielle

\title{
Asie centrale
}

\section{(2) OpenEdition \\ 1 Journals}

Édition électronique

URL : http://journals.openedition.org/transcontinentales/1493

DOI : 10.4000/transcontinentales. 1493

ISBN : 978-2-8218-1408-0

ISSN : $1775-397 X$

\section{Éditeur}

Editions de la maison des sciences de l'homme

\section{Édition imprimée}

Date de publication : 30 juin 2006

Pagination : 188

ISBN : 2200-92169-1

ISSN : $1950-1684$

\section{Référence électronique}

"Asie centrale », Transcontinentales [En ligne], 2 | 2006, document 28, mis en ligne le 15 décembre 2012, consulté le 25 septembre 2020. URL : http://journals.openedition.org/transcontinentales/1493 ; DOI : https://doi.org/10.4000/transcontinentales.1493

Ce document a été généré automatiquement le 25 septembre 2020.

Tous droits réservés 


\section{Asie centrale}

1 FATHI Habiba, Femmes d'autorité dans l'Asie centrale contemporaine, Paris, Maisonneuve \& Larose, IFÉAC, n.d., 348 p.

2 LARUELLE Marlène et Sébastien PEYROUSE (éds), Islam et politique en ex-URSS (Russie d'Europe et Asie centrale), Paris, L'Harmattan, 2005, $338 \mathrm{p}$.

3 RABALland Gaël, L'Asie centrale ou la fatalité de l'enclavement?, Paris, L'Harmattan, 2005, $347 \mathrm{p}$. 